\title{
Convergence Language Use in Nigerian Prose as a Platform for Human Development: A Study Of Chimamanda Adichie's Purple Hibiscus
}

\author{
Ngozi C. Nzeakor \& Patience Akunna Osondu \\ *http://dx.doi.org//I0.43/4/ujah.vI7i3.10
}

\begin{abstract}
All human activities are basically language based. This is to say that humans cannot do without language both verbally and nonverbally. Development of any kind cannot take place without language, this is because, it is language that propels human activities and co-operation. Co-operation cannot occur if humans do not observe certain nuances of language use. Language as a two edged sword can either lead to human development or mar it. So, as humans, if we want to develop economically, academically, socially, spiritually, politically etcetera, we should be able to know how to manipulate our language use to bring about cooperation which in turn brings about development. In order to achieve this, the researchers advocate the use of convergence principles in communication. Twenty- convergence conversations and twenty non- convergence conversations were systematically selected from the text. The accommodation theory by Howard Giles formed the theoretical framework of the study. At the end of the textual analysis, it was discovered by the researchers that convergence communication draw communicators closer to their communicants and as a result co-operation is achieved while non- convergence communication eschew communicators. The researchers therefore recommend that language users should endeavour to apply convergence language use because with that, they can achieve any kind of development humanly possible.
\end{abstract}

Key words: Language, communication, convergence, divergence, human development 


\section{Introduction}

It is language that makes us human and it is also language that conditions all human activities. No meaningful development can take place without the appropriate use of language, be it politics, religious, social, economical, mental, psychological etc. Development can only take place in an environment that is free from conflict, rancor, antagonism and serious altercation. It is language that can be used to overcome all these anomalies. Linguists foresaw the functions of language as a means of communication and an instrument of co-operation, hence their various definitions of language reflect these.

It is not surprising today that language which was meant for human communication and co-operation is taking another dimension in our society. It is now playing the part of a two edge sword which can cause development or mar development. This is as a result of our changing society which also reflects one of the characteristics of language dynamism. Nothing is static. It then behooves the users of language to look out for those linguistic nuances that can aid in building good human relationship which can help in cooperation to enable us develop in our different areas of endeavour. Here lies the accommodation principles, especially the convergence principles which emphasize how communicators should use language to draw their listeners closer to them. It is a principle drawn from the accommodation communication theory propounded by Howard Giles, a professor of communication at the University of California Santababara in 1991, to help solve the problems that emanate from communication among communicators

In other to do justice to this theory, a total number of forty (40) accommodation principles in language use were systematically selected from the text under discussion. 
Twenty (20) were of convergence principles and twenty (20) were of divergence principles. Two families from the text were used to exemplify these principles, the family of Eugene Achike and Ifeoma. Eugene represents divergence language principle while Antie Ifeoma represents convergence principle.

At the end of the analysis, the researchers discovered that communicators who apply convergence principles were more accommodating and as such got more co-operation from their communication partners and this cooperation contributed significantly to the progress of whatever they were involved in (development). Those who engaged in the use of divergence communication ended up in conflicts and in the extreme cases death which hamper human development in every ramification. Based on these observations, the researchers recommend that communicators at all levels of our society should endeavour to imbibe that convergence principles while communicating because it brings goodwill, cooperation, happiness and draw the communicants closer to their listeners. It contributes significantly to human development because conflict is avoided. They equally conclude that if all communicators shun the accommodation principles of divergence, our homes, communities, states, nation, will be free from rancor and conflicts which hamper developmental processes.

\section{Definition of Terms Language}

This term has attracted so many definitions from both linguists and non-linguists alike and each has tried to define it to reflect his area of specialization. Some of these definitions will be given and the one that best describes the topic under discussion will be selected. According to Hornby in Okpara, language is "the system of sounds and words used by humans to express their thoughts and feelings" (260). It connotes 
characteristic ways of talking, thinking and feeling about attitude goals and ideals. Emenanjo in Okpara defines language as a particular way of style of speaking or writing. It is that complete whole of communication which includes signs, symbols, knowledge, belief and customs and cultures and any other abilities of speech acquired by mankind for the sole purpose of communication and identity. (260) Language here is seen as the total configuration of a person or group of persons that enables people in the society share common information and ideas.

The Encyclopedia Americana international education 2000 edition, volume 16, defines language as the principle and richest means of communication used by human beings. "It functions primarily as a spoken means of communication" (19). This definition excludes non-verbal language use. Nevertheless, language as a system of communication is one of the biological characteristics that distinguish humans from other animals, bird, insects etc. All human communities posses language, thus it is perhaps the single most significant property that distinguish humans from other animals. Just as all living creatures depend on water and earth around us so also the society depends on language for its existence.

According to Fromkin, Rodman and Hymes, language is defined thus:

We live in a world of language, we talk to our friends, our associates, our wives and husbands, our lovers, our teachers, our parents, our rivals and even our enemies. We talk to bus drivers and total strangers, we talk face to face and over telephone and everyone responds with more talk. Television and radio further smell this torrent of words. Hardly a moment of our waking lives is from words (284). 
From this explanation of language, it indicates that everybody uses language and language is used to perform varieties of functions, but there is also an exclusion of the non-verbal aspect of language use. Again, Fromkin, Rodman and Humes, while still answering the question - what is language? explain that, "it is whatever people may do when they play, fight, make love or make automobiles". They however conclude by asserting that we are the animals that do this talk (I). This definition includes both verbal, nonverbal communication, non-linguistic, written to be spoken etc and it will be used to situate this work because the theory equally takes into consideration of all these.

The big question that requires an answer from all of us is - in our day to day language use, do we use it to draw people closer to us or do we use it to eschew people from us and what are the benefits we get from both? This paper is in a position to proffer answers to these questions if we actually want to develop.

\section{Communication}

Communication touches every sphere of human activity. It informs all of man's actions because it is occasioned by his need to interact with his fellowmen. It manifests itself in symbolic, verbal forms. Animal and trees also communicate, but it is man's ability to create symbols, ascribe meanings and interpret messages that elevates him above the status of the lower animals and gives form and character to his existence (Sybil J. Isaac C. Oludayo S. I). Communication also serves as an instrument of social interaction. It helps us to understand ourselves, to keep in touch with other people, to understand them and to predict their response to situations. It is a means by which power is acquired, exercised and sustained. It is the medium through which people in business, politics and the professions act and 
interact; exchange information and ideas; develop plans, proposals and policies, make decisions and manage men and materials.

The above brief consideration of communication emphasizes its importance in human interaction. Thus no institution can survive without communication and no developmental process can go on without communication. The universal nature of communication has led to countless definitions of the term. Some of these definitions will be examined in this paper. Communication can be defined as a quality of being able to communicate, that is to give or pass on information, feelings, diseases etc. Effective communication can be attained only when language is properly used both linguistically and pare-linguistically and these are what linguists refer to as linguistic and communicative competences. The knowledge of only the linguistic features of a language cannot make one communicate effectively but one has to look at other paralinguistic features that are involved in communication.

According to Ngonebu communication is any transmission of information from one person to another in order to elicit a response (50). Ifeoma defines communication as an interaction by means of signs and symbols. The symbols may be gesture, picture, plastic or verbal or any other which would serve as stimuli to behaviour (2I3). In the words of Eyre in (Sybil et al: 3) communication is not just the giving of information, it is the giving of understandable information and receiving and understanding the message. Communication is the transferring of a message to another party so that it can be understood and acted upon.

From the various definitions of communication, it shows that communication can only be attained only when language is properly used both in its linguistic, paralinguistic 
and non-linguistic forms. Language and communication are inextricably bound together.

\section{Forms of human communication}

ljeoma identifies the following forms of communication by human beings.

1) Verbal communication

2) Non-Verbal communication and

3) Non-linguistic communication

The verbal form has to do with all the spoken languages of human being. According to Wachukwu (5) "The spoken medium consists of a series of sounds that are perceived by the ears". The primary form of language is speech because it comes first both in the life of a people and the life of an individual. Language first existed in spoken form before the written form. Speech enables a face to face communication. It has repetitions, tones, and stresses which when properly used by human being enhances communication. Oral communication according to Sybil is a communication through the use of words. It may take an oral, form in which human speech organs are used to produce sounds or a written form in which human muscles are used to produce symbols (letters of the alphabet and words) (I5).

Non-Verbal Communication: These are all forms of language that are not spoken. According to Grombeck in Ngonebu (50), just as your voice gives meaning to your message through the aural channel, your physical behaviour carries meaning through the visual channel. Peal argues that non-verbal behaviour far outweigh the impact of words and powerful messages can be delivered without even opening your mouth, the finger pointed accusingly, a roll of the eyes, 
or a deep sigh. Other strong messages are communicated if you fold your arms across your chest, stand with your hands on your hips and feet apart or walking during a conversation (52). Keeping silent is also part of non-verbal communication. Pelt identifies three different channels by which we communicate non-verbally: body language emotional cues and dress pattern.

Body language include: the use of body movement and stance such as shrug of the shoulders, leaning towards a person, pacing around, facial expressions, such as shifting, narrowing or widening the eyes, blinking, winking and smiling, gestures such as pointing of a finger, raising the hand, pounding the podium and so on. Dress pattern someone's dressing says a lot about the person and person's message. It is a communication mode which can draw people towards you (convergence) and your message or away from you and your message (divergence). Emotional cues include physical expression of inner feelings. A giggle, a guffaw, a chuckles, even an open laughter can add different dimensions to a message. Emotional cues carry a lot of weight in any spoken message.

Non-linguistic communication: This is a type of communication that is not linguistic because it is neither spoken nor written and it is not constrained by such linguistic structures as phonology, syntax, semantics or morphology. It is non-verbal in that it does not involve signs, gestures, or body language. In this type of communication, there is great use of representation, pictorial or graphic signs. They convey a lot of meanings.

The novel under study contain all these forms of communication patterns. 


\section{Development}

\section{The concept of Human Development}

As a concept, human development has attracted so many definitions. For example human development is defined as the process of enlarging people's freedoms and opportunities and improving their well-being. Human development is about the real freedom ordinary people have to decide who to be, what to be, what to do and how to live (web). The objective of human development is to create an enabling environment for people to enjoy long, healthy and creative lives. Human development can simple be defined as a process of enlarging choices. Everyday human beings make a series of choices - some economic, some social, some political, some cultural etc. It is also a process through which these choices are enlarged and focuses on the outcomes of enhanced choices.

The above definitions represent a simple notion which has far-reaching implications.

Firstly, human choices are enlarged when people acquire more capabilities and enjoy more opportunities to use those capabilities. Secondly, economic growth needs not be seen as the ultimate goal of development. But income makes an important contribution to human well-being, broadly conceived.

Thirdly, human development concept implies that people must influence the processes that shape their lives. They must participate in various decisions and their monitoring and adjustment to improve outcomes where necessary. In the ultimate analysis, human development is a development of the people, for the people and by the people and the emphasis that people must be able to participate actively in influencing the processes that shape their lives. Development encompasses economic and human development. Language permeates all aspects of human 
endeavour. It is the store house of ideas which provides different ways of looking at the world in addition to empowering the users. All the complied interactions and cooperation among the members of a society is unthinkable without language. Language is the engine and power house which all humans activities such as social, political, education, religion etc revolve. Without language, there will be no society, no thought process, no polity, no democracy and no development. Language is the basis for human development and to ensure wholesome human development there is need for language users to accommodate each/one another which will serve as a taste case for our unity and progress.

Language bestows enormous power to those around us, we may speak words of comfort, courage, inspiration and love and if the words truly come from the heart, they will give these precious gifts to those for whom we speak. Words may begin a quarrel, or start a war, order a garden shade, or build a city, freeze and limit the heart and mind or open and liberate them. As the Russian writer Alexander Solzhanitsyn once wrote "one word of truth can change the whole word" in Katharine Watson (3).

\section{Areas that require development through Language}

These areas are:

I) Communicative use of language

2) The creative use of language

3) New aspects of human activities

4) Changing environment

5) The new role of verbal and visual signs and symbols

6) On technical and economic methods, all humans desire to live, learn and create abstracted from (Okpara 262)

Communication is a very important concept in human development and language provides the mental and physical 
apparatus for rapid social and future development and even more in our conceptual views of human existence and exchange of ideas, culture and technology

\section{Theoretical Framework}

\section{Accommodation and its Principles}

Accommodation Theory was propounded by Howard Giles a professor of communication of the University of California, Santa Barbara in 1991. This theory is a social linguistic theory which argues that when people interact they adjust their speeches, their vocal patterns and their gestures to accommodate others. It explores the various reasons why individuals emphasize or minimize the social differences between themselves and their interlocutors through verbal and non-verbal communication. This theory is concerned with the links between "language context and identity". It focuses on both the intergroup and interpersonal factors that lead to accommodation as well as the ways in which power, macro and micro-context concern affect communication behaviour.

Accommodation is one way of explaining how individuals and groups may be seen to relate to one another or each other. Wardhaugh (II3). This theory sprung from the awareness that, speakers are not merely "incumbents" of roles imposed on them by the society but rather are inquirers attempting to comprehend themselves and others. "Viewing individuals as objects called upon to modify their speech in accordance with socially, prescribed norms, leaves much to be desired in so far as it ignores the interactants' feelings and motives which undoubtedly inform and permeate the production and interpretation of their verbal output. It focuses on the interactive aspects of communication and highlights its negotiative nature" (Giles: 59). 
Giles went further to say that speech accommodation takes place when people modify their speeches so that it conforms more with the way their conversational partners speak. There is always subtle adaptations which tend to occur more or less consciously. The accommodation process involves the speed at which people talk and the length of both pauses and utterances, the kind of vocabulary and syntax used, as well as intonation, voice pitch and pronunciation. Giles and Coupland explain speech accommodation as "a multiple organized and contextually complex set of alternatives regularly available to communicators in face to face talk. It can function to achieve solidarity with or dissociation from a conversational partner and dynamically too $(60-\mathrm{I})$.

Furthermore, Giles and Coupland, (66) add we accommodate others by adjusting our communicational behaviour to the requisite roles that participants are assigned in a given context. Le Page extends this definition to put even more emphasis on the speakers creation of his identity "we do not necessarily adapt to the style of interlocutor, but rather to the image we have of ourselves in relation to our interlocutor" (28). He adds further that speaking is not merely a social act that involves others, it is also a personal act in that it helps create the identity one wishes to be seen as having in a particular set of circumstances.

In the words of Giles and Clair: languages is not a homogeneous, static system. It is multi-channeled, multivariable and capable of vast modifications from context to contexts by the speakers, slight differences of which are often detected by listeners and afforded social significance (17). Given the fact that even the most trivial aspects of speech and pronunciation can take on crucial importance, it stands to reason that individuals consciously or unconsciously, should among other things seek to eschew 
identification with others through language. It is in this light that accommodation theory has become an important issue in socio linguistics and social psychology. There are two main accommodation processes described by this Theory. These are convergence and divergence. Convergence refers to the processes, whereby two or more individuals alter or shift their speech to resemble that of those they are interacting with. It is a strategy whereby individuals adapt to each other's communicative behavior in terms of a wide range of linguistic-prosodic, non-verbal features including speech rate, pausal phenomena and utterance length, phonological variants, smiling, gaze and so on. It is strategies employed by individuals in communicative behaviour so as to reduce their social differences. It is a shift in behaviour to become more like the other for social approval. Convergence always takes place when the speakers like one another or where one speaker has a vested interest in pleasing the other or putting them at ease. Converging towards the speech of another person is usually considered a polite speech strategy and it implies that the addressee's speech is acceptable and worth imitating. Also using the same pronunciation and the same sort of vocabulary for example is a way of signaling that you are on the same wave length. Convergent communicative acts reduce interpersonal differences and inter individual variability (Delis and Clark 16). Convergence behaviour indicates positive relationships.

According to this theory, convergence can either be upward or downward. An upward convergence happens when one seeks the approval of someone of high status. It is a movement towards the speech of someone with more powers, or status or someone deserving respect in the context, while downward convergence refers to convergence towards the speech of someone with less status or power. Convergence behaviour indicates positive relationships. 
Furthermore, divergence or non-convergence takes place when a speaker signals social distance or disapproval by using a language variety that differs from the style of the other speaker. This behaviour contradicts the method of adaptation and in this context the individual emphasizes the social differences and non verbal differences between the interactants. It also involves a deliberate choice of a language not used by one's addressee. Deliberately choosing of a language not used by one'saddressee is the clearest example of speech divergence. Divergence behaviour can be putting on air and graces in order to deliberately dissociate yourself from peers, or acting boorishly at a weeding reception. The particular behaviour involved may be of various kinds not necessarily speech alone, types of dress, choice of cultural pursuit etc. Divergence is behind exaggerating differences.

Divergence in speech does not always indicate a speaker's negative attitudes towards the addressee, if the divergent forms are admired. Divergence can be used to benefit the diverger. The two processes of convergence and divergence usually are dependent on the characteristics of the interactants, people accommodating their communication while interacting with a person who has higher standards and other characteristics which they believe are better than theirs. A speaker may also deliberately diverge both from his own usual speech style and that of their addressees towards the style of a third party for special effect. This is labeled referee design. The third party referred to is not present.

There are certain criteria for identifying speech accommodation both for downward convergence and upward convergence. When people converge downwardly, they make use of simple sentences linked by co-ordinators (and, but). More explicate sentences and there is room for reference. But for upward convergence, they use more high 
sounding words, more subordinate clauses and complex sentences.

There are also four major assumptions under which this theory is based.

These are:

$>\quad$ While communicating there will be similarity in and difference in the speech and behaviour. The characteristics that people exhibit are based on our experiences and the cultural background that we grew up in.

$>$ A conversation is evaluated by understanding the perception of the speech and behaviour of the other. Through evaluation people decide to accommodate and fit in

$>\quad$ The social status and belonging is determined by language and behaviour, while people communicate they tend to accommodate the behaviour of those who are in the higher social status than them.

$>\quad$ Finally, Norms guide the accommodation process which varies in the degree of appropriateness. Norms define the behaviour of people and they are expected to act accordingly.

There are so many factors that make people accommodate others, these are age, sex, academic qualification, culture, status, religious denomination and others.

\section{How do Speakers Accommodate Others?}

According to Wardhaugh speakers accommodate interlocutors in the following ways:

I. When you respond to and develop a topic introduced by your addressee, you are converging in the content of the speech of the addressees. 
2. When people simplify their vocabulary and grammar while talking to foreigners or children, they are converging downwards. Towards the lesser linguistic proficiency of their addresses.

3. When a complicated technical message is translated for the benefit of someone who does not know the jargon, speech accommodation is involved.

4. When someone adopts the pronunciation of another person higher in rank or academics, the person is converging upward in his speech.

5. When a person chooses a variety of language that is most comfortable for his addresses, the person is being accommodative.

6. In the market place, people sometimes accommodate to the language of the person selling goods in order to secure goodwill and hopefully, a good bargain.

7. When people codeswitch they are being accommodative. He further adds that by codeswitching in a conversation a speaker can both access different identities and accommodate to meet someone else half-way, establish common ground and show flexibility and openness (Wardhaugh II5).

The accommodation theory is appropriate for the analysis of the text under discussion because there are lots of convergence and divergence features portrayed in it.

\section{Brief Biography of Chimamanda Ngozi Adichie}

Chimamanda Ngozi Adichie was born in Abba, Anambra State on September 15, 1977. She grew up on the campus of University of Nigeria, Nsukka, where both her parents worked. Her father was Nigeria's first professors of statistics and her mother was the first female registrar. Adichie completed her secondary education at the university's school, receiving several academic prizes. She 
began her tertiary education at the same University, studying medicine and pharmacy. While at Nsukka, she edited compass magazine for the catholic students of the Medical school. Her first 19 years spent in the campus environment have influenced her first two novels, which draw richly on this settings as a backdrop to the lives of the novel's characters.

After a year and a half at Nsukka, she won a scholarship and left for the United States where she attended Drexel University, Philadelphia. She later transferred to Eastern Connecticut State University, graduating Summa Cum Laude in (200I) with a degree in Communication and Political science. Adichie went on to study at Johns Hopkins University (2003) and Yale University (2008). She was a Hodder fellow at Princeton University (2005-2006).

Her first novel, Purple Hibiscus was shortlisted for the orange prize for fiction (2004) and was awarded the common wealth writers' prizes for Best First Book (2005). Her second novel, Half of a yellow sun won her the orange prize for fiction in (2007) and was made into a film in (2013). Her last novel Americanah published in (20I3) has received many accolades. Adichie divides her time between the United States and Nigeria, where she organizes annual creative writing workshops, along with other writers, to encourage upcoming authors. Adichie has been referred to as the most prominent of a procession of critical acclaimed young Anglo phone authors that is succeeding in attracting a new generation of readers to Africa.

\section{Analysis of Purple Hibiscus}

Purple Hibiscus is a multi-dimensional novel which gives room to several interpretations. It is indeed a novel that portrays and connects with society. One of the crucial and over-ridding issues raised in the novel is religious fanaticism 
and intolerance. Religion which is supposed to be a moralizing and sanitizing agent is misapplied and becomes a source of conflict. It has become a knotty and controversial issue resulting to crisis in Nigeria, Africa and the world over. Adichie takes a swipe at this anomaly, wondering why religion has become the cause of turmoil, and crisis in human societies.

Religious extremism as is common in today's world has led to strife, acrimony and instability causing more harm than good. In Nigeria, religious extremism has sparked off conflicts particularly in the northern part of the country between Moslems and Christians leading to massacres and wanton destruction of lives and property Arguably, most of the crisis and upheavals in the Middle-east can be attributed to religious fundamentalism Sadly enough, even in mono religious nations, religious extremism still poses a great threat Typical examples can be found in the hostilities that exist between Shites and Sunni's in Iran and Iraq, Catholics and Protestants in Northern Ireland where the I.R.A. (Irish Republican Army) has in the last fifty years been intervening and mediating.

Basically, Adichie in this novel criticizes religious fundamentalism, killing, maiming, destruction of property and discrimination all in the name of religion. Essentially this novel questions religious rigidity and conservative ideology. Religious fundamentalism amounts to mortals fighting God's battle as though God were weak or needs the service of man to wage battle on His behalf, or force people to follow Him through a particular religion. This is rather sad and ironic because most religions preach peaceful co-existence and tolerance for other peoples' beliefs and ideologies. Adichie in this novel is objective although quite hard on religion and Catholicism in particular. In an interview with Wale 
Adebanwi, in Inedu (55) she blames religion for "feeding people so much nonsense in God's name..."

She tells Ryan Snictecki in another interview that:

"I am a Catholic but I worry about the version of God that the Catholic Church teaches"... when I say I am a Catholic for some people, it comes with so much baggage. I love Mass, I love the rituals and the drama of the church, but there are so many things I have problem with".

Perhaps one of the things she is not comfortable with is celibacy in priesthood. She courageously raise this controversial, crucial and poignant questions. She further tells Adebanwi that "I wanted to write about how I wish that people would be more accommodating in their faith... its fine to be a Catholic but people who choose to follow the old way of ancestral worship are not devils." She subtly $\mathrm{x}$-rays the legitimacy of Igbo tradition and religion which is obvious when observed vis a vis Catholic ritual. As the plot of the novel thickens, Adichie puts Catholicism against traditional African beliefs; Catholicism's best and worst qualities manifest themselves in Kambili's father Eugene and the young priest Father Amadi who unintentionally steals Kambili's heart. Purple Hibiscus is a somewhat familiar study of all the political tension and identity crisis that still define postcolonial Africa.

With the geographical setting in the lgbo region of eastern Nigeria, one gets a taste of the shackles and nuances of contemporary Nigerian life. Adichie's picture of Nigeria's domesticity is troubled; the story is shaped fundamentally by political upheavals around it and is set within a dysfunctional family in an equally dysfunctional Nigerian society. Another crucial issue raised in the novel is that of molestation and 
violence e.g women and children. It is common knowledge that women and children particularly in Africa are susceptible to violence and suffer marginalization and molestation from men and society in general. Sadly enough, our cultures and traditions encourage and give room to this anomaly. Women and children are truly an "endangered species" as has been argued by feminists such as Zainab Alkali, Buchi Emecheta, Catherine Acholonu. etc They are prone and vulnerable to attacks with their rights violated and often times treated as second class citizens, negating and going contrary to the Geneva convention which prescribes total respect for the rights of women and children. Adichie, through this novel, brings to the fore the molestation of women and children prevalent in our society and challenges the status-quo, in the process making a bold statement on behalf of women and children in Africa.

Torture and brutality are graphically treated by Adichie. These are as a result of dictatorship and tyranny particularly by military juntas in Africa. The problem of misrule and military incursion and dictatorship that is prevalent and a common feature in Africa is presented. There are coups and counter coups by soldiers who abuse their office, molesting civilians, harassing journalists or anyone who challenges or criticizes their authoritarian rule. In a review by Ogoke I an Angolan reader sees it as a mirror of Angola, where there is also constant power outage, no water, no milk, where lantern is still used, and where non payment of teachers' salaries is the order of the day. ljeoma goes on to argue that "From another angle Purple Hibiscus resembles, in many ways, the anti- colonial novels which feature primarily, a satirical treatment of colonial implantation in Africa" (48)

Adichie also tackles some economic and social problems facing the nation. She dwells on how leaders and politicians abuse office and misappropriate public funds. She 
also highlights poor living conditions of the masses especially in rural areas, bribery and corruption as typified by the Police Force, poor working conditions for workers, incessant power failure, and lack of basic social amenities. Fuel scarcity also features prominently in the novel. She uses this to ridicule Nigeria. Although the sixth largest producer of oil in the world, the country still suffers shortage of domestic fuel. Most of all, the preponderance of poverty and want in the midst of so much national wealth.

Since part of the novel is set in the university town of Nsukka, Adichie uses the opportunity to address some fundamental challenges bedeviling the nation's educational sector. Deterioration in the educational system, poor funding of education, poor remuneration for teachers leading to strikes and brain drain and above all, the militarization of the educational institutions where a military man is made the Vice Chancellor of a university. Perhaps, she does this to criticize the imposition of an army General as a sole administrator of one of Nigeria's premier universities. Most of these problems she associates with "some big men in Abuja" a phrase she uses often to portray and indict corrupt politicians who divert public funds meant for the development of the nation to their personal use.

We are also presented with the issue of Blacks (Nigerians) feeling inferior to whites. It is common knowledge that perhaps due to colonialism, some blacks see themselves as inferior beings compared to whites, even the educated ones have a prejudiced notion about themselves thereby undermining their self worth. Eugene more than any other person in the novel demonstrates this. He prefers the white priests to black priests insisting that they are holier. He always tries to impress them by relegating his lgbo language to the background. He encourages English language to be spoken even by village folks who slavishly attempted to speak 
English to the admiration of the whites whom he openly confesses are better and more civilized than blacks. Adichie tactically condemns this.

The many social and economic problems reflected by Adichie in this novel are still topical issues and challenges that face Nigeria even today. This is an indictment of our social and economic structures. She has through this work consciously tackled real issues that bother Nigeria. She does not shy away from these issues rather she realistically presents and criticizes them perhaps to effect change and bring some level of sanity to the polity. Adichie has essentially through this novel realistically $\mathbf{x}$-rayed a variety of crucial and pertinent issues as they affect man and society.

\section{Examples of Non-divergence Language use in the Novel}

I) Things started to fall apart at home when my brother, Jaja did not go to communion and papa flung his heavy missal across the room and broke the figurines on the etagere. This is a sign of unhealthy relationship. It is action packed. The person who perpetrated this mayhem is the father of the home and his action was occasioned by his son's refusal to take Holy Communion on an ash Wednesday. His action portrayed a divergence behaviour. There are off course other means to effect corrective measures rather than destroying things in the home. The effect of his action was disastrous and marred the mental development of the members of his family.

2) She nodded quickly, then shook her head to show that the figurines did not matter. They did, though years ago before I understood, I used to wonder why she polished them each time I heard, the sounds from their room, like something being banged against the 
door. Her rubber slippers never made a sound on the stairs, but I knew she went downstairs when I heard the dinning room door open. I would go down to see her standing by the etagere with a kitchen towel soaked in soapy water. She spent at least a quarter of an hour on each ballet dancing figurine... (18) The woman (Beatrice Eugene's wife) is facing some psychological trauma because of her husband's non accommodating nature (divergence behaviour), that she finds solace in the cleaning of the etagere each time she was battered by her husband. Imagine the waste of time, time that should be spent in some lucrative things was spent cleaning an ordinary etagere. According to Ogwude in Tydskrif "His wife, Beatrice's polishing of the etagere was a way of containing her emotional and psychological turmoil after each physical assaults (II3). How can a woman who is not emotionally and psychologically balanced contribute to the development of her family and society at large?

3) "Ask that girl to bring it", papa said (20). The girl in question here is the house help but the way/tune she is being addressed here seems as if she is a stranger. There is a wide gap between master and servant. At least that girl can be addressed by her name - Sisi to look more accommodating. No wonder she aided in the poisoning of her master (Eugene).

4) Papa was staring pointedly as Jaja. "Jaja have you not shared a drink with us gbo? Have you no words in your mouth? He asked, entirely $n$ lgbo. $A$ bad sign. $\mathrm{He}$ hardly spoke Igbo, and although Jaja and I spoke it with Mama at home, he did not like us to speak it in public. We had to sound civilized in public, he told us, we had to speak English (2I). Here, Eugene is not at 
home with his native tongue, he speaks it only when there is a serious problem in the home. (a bad sign). From what researchers reported, no country can develop politically, socially, religiously etc without the use/knowledge of the language. The cited Japan which has the highest industrial development as using their indigenous language. Again, Jaja is having an internal conflict with his father's attitude in the home and as such diverges from every member of the household. $\mathrm{He}$ decides not to contribute anything to meaningful to the family discussion. His silence caused a lot of problems in their home as can be seen in the next line.

5) "Have you nothing to say, gbo, Jaja?", papa asked again. "Mba, there are no words in my mouth", Jaja replied. (2I). "What?" There was a shadow clouding papa's eyes, a shadow that had been in Jaja's eyes. Fear. It had left Jaja's eyes and entered Papa's (2I). From this quotations we see tension, conflicts, uncooperative behaviour, and fear. Can a country with such families develop? And there is a saying that the family is the bedrock of the society. When the family is sick it signifies a sick society and no meaningful development can take place. The actions above led to what happened in the next quotation.

6) I didn't know what else to do. this had never happened before in my entire life never. The compound walls would crumble, I was sure and squash the frangipani trees. The sky would cave in. The Persian rugs on the stretches would ... shrink ... My body shook from coughing (22). These are actually the situations of not being accommodating in nature.

7) "Let me pour your tea" She offered, although she never served papa's tea. Papa ignored her and poured 
his tea... (29) Beatrice tried to accommodate her husband (Eugene) but she was ignored (diverged). (Her feelings were hurt).

8) I was in my room after lunch... When I heard the sounds. Swift, heavy fluids on my parent's hard-carved bedroom door..., I heard the door open... papa descend, mama was slung over his shoulder like the lute sacks of rice..., there is blood in the floor which led to a miscarriage (4I) (wife battering) non convergence or divergence behaviour. According to Ogwude in Tydskrif "Not even the pregnancy of a much awaited child is enough to persuade Eugene against executing God's imagined justice on his hapless and long suffering wife whose physical demands as a result of early pregnancy could not be countenanced (133). How can a woman in such a situation contribute to development. Again, the child that was miscarried as a result of the assault melted to the woman could be the president of Nigeria tomorrow. What a great loss!

9) Papa, closed the Bible "Kambili and Jaja, you will go this afternoon, to your grand father's house and greet him. Kevin will take you. Remember, don't touch any food, don't drink anything and, as usual, you will stay not longer than fifteen minutes. Fifteen minutes". (69) (The underlined lines are mine and signifies bad language use). First, he used an exclusive pronoun your not my father, but your grand father, as usual means that he has been doing that, that this was not the first time and finally, he gave them only fifteen minutes and equally emphasized it. That is to say that if they spent more than that they will be punished. Is this practical Christianity? Where will this attitude take us to? Ogwude has this to say concerning 
Eugene's type of Christianity "Eugene Achke's religious fervor is essentially empty and devoid of basic Christian tenets. He is evidently oblivious of the fact that ... abuse and an absolute lack of humanness is anathema to Christianity and to all well known Christian values. (143).

10) Papa himself never greeted papa nnukwu, never visited him, but he sent him words of naira through Kevin or through one of our Umunna members, slimmer wards than he gave Kevin as a Christmas bonus (10). This is the height of non-accommodation behavior. What do you think will be the effect of these? He went further to say.

II) "I don't like to send you, to the home of a heathen, but God will protect you" Papa said (90), is this what the Bible preaches? That we should not associate ourselves with sinners? That we should abandon our parents because they are heathens? According to Luke Chapter 5 verse 32 "Christ said "You have not come to call the righteous, but sinners, to repentance" (1468). Everything that Christ did was centered on love.

12) Papa-Nnukwu had never set foot in it, because when Papa had decreed that heathens were not allowed in his compound, he had not made an exception for his father (70). How can a country develop when Christians cannot even show love to others no matter their religious inclination. What about the aged in our society? Are they so useless that they cannot contribute meaningfully to the development of our country? I still remember vividly this saying - the words of the elders are words of wisdom and I know that wisdom is the highest virtue that any man can have. So, what happens if they are allowed to die? 
Speech accommodation, especially the convergence type is what we need.

13) "I didn't even know about the award" Aunty Ifeoma said. "Not that Eugene would tell me anyway [gas[kwa. We can't even have a conversation (I45) Eugene is so distance from his family that he never discuss relevant issues with his family members especially Auntie who is a lecturer at UNN. I think as a university graduate, she is in a better position to contribute significantly to Eugene's family development.

14) When the death of Eugene's father was reported to him, his reaction talked human feelings. Let's see: "Eugene, our father has fallen asleep". Aunty Ifeoma said. Papa stared at her for a while, surprise ... when?" Papa sat down and slowly lowered his head into his hands and ... But when he looked up, I did not see the traces of tears in his eyes. "Did you call a priest to give him extreme unction?" he asked ... "is that all you can say, eh Eugene? This is purely inhumanity to a father under the pretext of religious zealousness.

15) Aunty Ifeoma got up and started to short. Here voice was unsteady "I will put my dead husband up for sale Eugene, before I give our fathers a catholic funeral. Do you hear me?.. was our father a catholic? I ask you Eugene, was he a catholic uchu gba gi"... Tears rolled down her cheeks. She made choking sounds as she turned and walked into her room (195). This is a sign of bad relationship and not being accommodative by Eugene. Christianity is not done by. There is a language for it - accommodating language.

16) Mama was at the door when we drove into our compound. Her face was swollen and the amear 
around her right eye as the black-purple shade of an overripe avocado (197) (wife bettering)

17) ... I saw a woman spit at a soldier, I saw the soldier raise a whip in the air. The whip was long. It curled in the air before it landed on the woman's shoulder. Another soldier was kicking down trays of fruits, squashing papaya with his boots and laughing. (32) This is a state of anarchy. Soldiers who are meant to protect the citizenry are busy themselves beating and deriving pleasure in what they were doing - laughing as they inflict pains on the women. It is difficult for a society under this condition to develop. Eugene did not allow his children to socialize and that got them different negative names and attitudes. And because they did not socialize, they had little or nothing to contribute towards any useful discussion for example.

18) "Chinwe just wants you to talk to her first" Ezinne whispered "you know, she started calling you backyard snob because you don't talk to anybody (59) Again auntie Ifeoma's daughter noticed her asocial life and she said: "Are you insane they are not abnormal, mum Kambili just behaved like an atulu when my friends came" ... She behaves funny. Even Jaja is strange. Something is not right with them". (I50). These behaviour was as a result of the type of regimented life they were exposed to by their father. It was their that does the thinking for them. In support of the stand of the researchers, Ogwude said: by the time we meet the child narrator, she had unintentionally become "a backyard snob to most of (her) class girls" (52) and had since been consigned to the unsociable group of her class. Her regimental upbringing did not allow her to socialize with her 
mates. (I I4). In this case, their brains were meant for decoration.

19) Mama's low voice floated across the phone line and quickly quelled my shaking hand. Kambili. It's your father, they called me from the factory, they found him lying dead on his desk", (290). This is the climax. The result of an unaccommodative person death.

20) "They did an autopsy" she said they have found the poison in your father's body"... "I started putting poison in his tea before I came to Nsukka, Sisi got it for me, her uncle is a powerful witch doctor (294). It is hardly surprising that Eugene died from poisoning from his wife and her maid Sisi. Eugene died out of his religious chauvinism, autocracy and cultural hostility, etc. These words are unaccommodating and non convergent to divergent. They cannot help in any meaningful development, be it families, state and nation at large.

\section{Convergence Language use by different Characters in the Novel Purple Hibiscus as examplied by Aunty Ifeoma and her family}

The beginning sentence started with

I) Laughter always rang out in Aunty Ifeoma's house and no matter where the laughter came from, it bounced around all the walls, all the rooms (148). People laugh when they are happy, love yields happiness and happy people live in harmony and are more accommodative. People who are happy have related mind which enable them to plan ahead,

2) Arguments rose quickly and fell just as quickly. Morning and night prayers were always peppered with songs Igbo praise songs that usually called for hand clapping (148). Accommodating the Igbo language, no discrimination. 
3) Amaka, you are free to have your opinions, but you must treat your cousin with respect. Do you understand? Aunty Ifeoma replied in English, her voice $f$ (150) In Ifeoma's home everybody's opinion matters. She accommodate all.

4) Some of the children from the flats upstairs came down and stood watching us. They were about five, all a blurf food stained clothes and fast words. They talked to one another and to Aunty Ifeoma and then turned and asked me what school I went to in Enugu (5I). These children were made to socialize with Ifeoma and her niece and nephew but the regimented life seen Eugene's home.

(5) "Amaka, you are free to have your opinions, but you must treat your cousin with respect. Do you understand that?" Aunty Ifeoma replied in English, here voice firm. (I50) (a light reprimand to correct a non-accomodative behavior).

(6) Some of the children from the flats upstairs came down and stood watching us. They were about five, all a blur of food stained clothes and fast words. They talked to one another and to Aunty Ifeoma and then one of them turned and asked me what school I went to in Enugu (I5I) (this is a sign of socialization and it is a convergence behaviour),

(7) Aunty Ifeoma smiled. "Don't they say that time flies when you are happy?" (154)

(8) "I worry about your father," Mama said, before I gave the phone to Jaja. "I worry about your father" (I54) (sign of love).

(9) When papa called later, he asked to talk to Aunty Ifeoma first afterwards he talked to Jaja and then me. He said everything was fine... Aunty Ifeoma said, "Your father wants you to stay here few days longer," and Jaja smiled so wildly I saw dimples I did not even know he had. (I55) 
(transformation from an autocratic, secluded life style to a democratic, inclusive life style).

(10) “Why didn't you tell me you would be playing today, father?" Obiora asked. "I'm sorry I forgot to, but I will pick you and Jaja up next weekend so we can play." (I56) The music of his voice lowered in apology. I could not help staring at him, because his pulled me and because I did not know a priest could play football. It sound so ungodly, so common. (I56).

(II) "Ifeoma, is something wrong?" Father Amadi asked she shook her head and sighed as though she had just realized that she was not alone. "I got a message from home, today. Our father is sick..... I want to bring him here (156) (she did not say my father or their Papa Nnukwu but used ' Our' accommodating everybody as having something to do with Papa Nnukwu. The father equally showed concern about Aunty Ifeoma's feelings (accommodation)

(12) “Ezi okwu? Father Amadi's brows sorrowed. "Yes, you should bring him here" (156). (concerned)

(13) “Papa-Nnukwu is sick?". Amaka asked shrilly. "Mum when did you know?" (156) "This morning, his neigbour called. She is a good woman. Nwamgba, she went all the way to Ukpo to find a phone" (156) (Every member of the family showed concern over Papa's ill health while Aunty Ifeoma was complaining about her handicap in terms of not having enough fuel in her car that will enable her to go home to fetch papa Nnukwu, father Amadi came to her rescue.

(14) "We have some emergency fuel reserves, in the chaplaincy, "Father Amadi said quietly. "I am sure I could get you a gallon. Ekwuzina, don't sound that way" (I57). (Trying to carry another person's burden as if it is his own). 
(15) Aunty Ifeoma came back in the afternoon when the buzz of a bee around the garden was almost lulling me to sleep. Obiora help Papa-Nnukwu out of the car, papa Nnukwu leaning against him as they walked into the flat. Amaka ran out and pressed her side lightly to papa Nnukwu's. His eyes dropped .... But he smiled and said something that made Amaka laugh (159) (Everybody provided succour that the old man smiled even in his critical situation).

(16) “I will make ofe nsala for dinner Papa Nnukwu likes that, Amaka said.

"I hope he will eat. Chinyelu said even water has been hard for him to take in the last two days" 160.

(17) When father Amadi blew the final whistle, three times with the last time drawn out, then the boys clustered around him, heads bowed while he prayed... there was something confident about his gait like a rooster in charge of all the neigbourhood hen (185) (This is what happens when people have an accommodating hearts).

(18) “I see Christ in their faces, in the boys' faces" but Kambili, a naive girl could not make meaning out of this statement. He went further to explicate what he meant in $18 \ldots$

(19) “They live in Ugwu Oba. Most of them don't go to school anymore because their families can't afford it (I85). (Yet they were all happy).

(20) "Mum how did it go? Did you get it?"

"I got it," Aunty Ifeoma said, coming out to the verandah.

"You got the visa" Obiora screamed rushing over to hug his mother (282).

(2I) Aunty Ifeoma cooked dinner for father Amadi and we all ate the rice and beans at the dinning table. I knew there was much laughter, much talk... (286). 
(22) I laughed it seemed so easy now, laughter. So many things seemed easy now Jaja was laughing, too as was Amaka ... He walked up slowly (288).

(23) "Amaka, please answer it," Aunty Ifeoma said even though she was closest to the door. (289).

(24) "I can guess it's for you Mum" Amaka said focused on her cards. It's one of those people who want you to dash them our plates and pots and even the underwears we have on" (209) Aunty Ifeoma is a cheerful giver, she does not attach anything to her giving.

(26) Aunty Ifeoma got up laughing and hurried to the phone. The TV was off and we were all sitantly absorbed in our cards, so I heard Aunty Ifeoma... (290). At the end, Aunty Ifeoma and her family travelled out of the country at the climax of hard economic crunch. Her family was missed by Jaja and Kambili

\section{Recommendations}

Having analyzed the convergence and divergence principles of accommodation, it is quite convincing that for any meaning development to take place communicators should do the following:

I) Be mindful of their language use as this could build or mar development

2) Should always aspire for convergence behaviour in language use as this draw them closer to their listeners and yield co-operation which is what is needed for human development.

3) Language education should be mounted by language experts to reach language users the pre-requisite for language communication

4) Finally, communicators should shun the use of divergence language so as to enable us develop, 
mentally/psychologically, educationally, economically, politically etc.

\title{
Conclusion
}

Language which is what differentiates humans from other organisms has in the recent times caused havoc rather than co-operation because language users have neglected an important aspect of it - accommodation principles especially the convergence type. As a result of this neglect, developmental processes are slow. No meaningful human development can take place without recourse to language and indeed a good one. It is here that the accommodation (convergence) play an important role. It aids in conflict resolution and make users of language to be in love, harmony, peace and happiness which are the major indices for development. All language users, parents, teachers, government, pastors etc should acquaint themselves with the nuances of this communication strategy to enable them win their communicants and to draw them closer to them for a peaceful co-existence and human development. This language use should start from the family because it is often said that a united family is a united nation and charity begins at home. If other homes are peaceful, our society and nation will develop beyond human expectations.

\author{
Ngozi C. Nzeakor \\ Department of English Language \&Literature \\ Alvan Ikoku Federal College of Education Owerri, \\ Nigeria \\ $\&$ \\ Patience Akunna Osondu \\ School of General STUDIES \\ Alvan Ikoku Federal College of \\ Education Owerri, Nigeria
}




\section{Works Cited}

Adichie, Chimamanda Ngozi. Purple Hibiscus. Nigeria: Farafina Imprint (2006).

Arome Lonie Acholo. Language education and National transformation in the journal of the Inter College Association of French teachers in Nigeria (NTERCAFF) Vol. 9 No. 2 Oct, 2014.

Eminue, O. Conflict Resolution and Management in Africa. A Parnorama of conceptual and theoretical issues in African journal of international Affairs and development, Vol. 9. No. I and 2. (20I4).

Fromkin, V.B., Rodman \& N. Hymes An Introduction to language ( $8^{\text {th }}$ ed) USA: Thomas Wardsworth. (2007).

Giles, Howard. Language, contexts and consequences. Keynes: Open University press. (1991).

ljeoma, C.P. Communication, Language and the arts Readings in African Humanities African Perspectives in Egonu (ed) world Culture. Owerri: Vivians and Vivians publishers (1988).

Inedu, E. Narrativity in Chimamanda Ngozi Adichie's Purple Hibiscus and Half of a Yellow Sun in his master's thesis (20I0).

Katharine Watson English The Origin History and Development of the Language. London. St. James Publishing (2002) print.

Ngonebu, C.I. Fundamentals of second Language learning. Nsukka: Afro Orbis Publishers.

Ogujioba, A. Personality Chimamanda Ngozi Adichie. This day, Sunday, May (2007: 57).

Ogwude S.O. History and Ideology in Chimamanda Adichie fiction, in Tydskrif cir letterkunde association South Africa (20I0). 
Otite Onigu \& Isaac Olawata, A. Management, Reduction and transformation. Ibadan: spectrum books Ltd. (1999).

Pelt, N.C. Hart to Hart. The art of communitation. Spain: San Farnando Dehenaren (2015)

Sybil James, Isaac Ode and Olydayp doola Introduction to communication for Business and Organizations. Ibadan: Spectrum Limited (2007) Pant.

The Encyclopedia Americana International Edition, Edition, Vol. 16, Grolier incorporated. (2000).

The Longman Dictionary of Contemporary English Pearson Limited. (2009)

Thomas John, new King James Version Colombia: Thomas Nelson. (1994).

Wachukwu, L.I. Introduction to the phonetics and phonology of English. Nigeria: Laura publications (2007).

Wardhaugh, Ronald. An introduction to socio-linguistic $\left(6^{\text {th }}\right.$ ed). United Kingdom: Wiley-Blackwell publishing Itd (2002).

www.measureofamerica.org $>$ humandevelopment.accessed $\underline{27 / 04 / 2016}$ 